\title{
Immunoreactivity of $c$-kit Receptor Protein during the Prehibernation Period in the Oviduct of the Chinese Brown Frog, Rana chensinensis
}

\author{
Yong SHEN ${ }^{1)}$, Yuning LIU $^{1)}$, Jiajia MA ${ }^{1)}$, Xiaoting MA ${ }^{1)}$, Yang TIAN $^{1)}$, Haolin $Z_{H A N G}{ }^{1)}$, Lin LI $^{1)}$, Meiyu XU ${ }^{1)}$, \\ Qiang $\mathrm{WENG}^{1,2) *}$, Gen WATANABE ${ }^{2,3)}$ and Kazuyoshi TAYA ${ }^{2,3}$ \\ ${ }^{1)}$ College of Biological Science and Technology, Beijing Forestry University, Beijing 100083, China \\ ${ }^{2)}$ Laboratory of Veterinary Physiology, Tokyo University of Agriculture and Technology, Tokyo 183-8509, Japan \\ ${ }^{3)}$ United Graduate School of Veterinary Sciences, Gifu University, Gifu 501-1193, Japan
}

(Received 24 January 2011/Accepted 8 September 2011/Published online in J-STAGE 22 September 2011)

ABSTRACT. The objective of this study was to investigate immunoreactivity of the $c$-kit receptor in the oviduct of Rana chensinensis during the prehibernation period. Histological examination of oviducts was performed during the prehibernation period. The sections of oviduct were immunostained by the avidin-biotin-peroxidase complex method using rabbit polyclonal antisera raised against the rat $c$-kit receptor and PCNA. Total proteins were extracted from oviducal tissues and used for Western blotting analysis. Immunohistochemistry revealed the presence of the $c$-kit receptor and PCNA in the oviduct tissues during the prehibernation period. Also, positive signals for the $c$-kit receptor and PCNA by Western blotting were observed in oviduct tissues during the prehibernation period. These results suggested that the $c$-kit receptor might play a regulatory role in oviducal hypertrophy in the brown frog, Rana chensinensis.

KEY WORDS: c-kit receptor, oviduct, Rana chensinensis.

doi: 10.1292/jvms.11-0033; J. Vet. Med. Sci. 74(2): 209-213, 2012

The $c$-kit proto-oncogene encodes a transmembrane receptor and is associated with maturation of several cell types, including germ cells. The gene is widely expressed as a single 5-kb transcript localized to human chromosome 4 and to mouse chromosome $5[5,12,19,39]$. The $c$-kit receptor whose ligand is a stem cell factor (SCF) belongs to the family of receptors for platelet-derived growth factor and colony-stimulating factor. It plays an important role in the signal transduction pathway that regulates cellular growth on repair [37]. The $c$-kit receptor is the gene product of the murine white spotting (W) locus [1, 26] mutation, which leads to defects in hematopoiesis, melanogenesis and gametogenesis [12]. The expression of $c$-kit receptor has been detected in various normal, fetal and adult tissues, including the gonads, brain, adrenal gland, skin, breast and bone marrow, and in several human malignancies like seminomas, including lung and brain cancers and glioblastomas [14, 16, 32]. The $c$-kit proto-oncogene encodes the receptor tyrosine kinase kit, which has also been shown to be important for normal mast cell survival, proliferation, differentiation and migration $[6,7,27,35,40]$. Evidence has accumulated that the $c$-kit receptor plays a critical role in the development of the mammalian ovary, oogenesis, folliculogenesis, blastocyst implantation and uterine growth and repair [8, 13, 22, 33]. Recently, the $c$-kit receptor has received increasing attention for its role in the reproductive function of lower vertebrates $[18,29,41]$.

\footnotetext{
* Correspondence to: Weng, Q., Laboratory of Animal Physiology, College of Biological Science and Technology, Beijing Forestry University, Beijing 100083, People's Republic of China. e-mail: qiangweng@bjfu.edu.cn
}

C2012 The Japanese Society of Veterinary Science
The Chinese brown frog (Rana chensinensis) is a special amphibian in northeastern China, as it has been used widely in traditional Oriental medicine [42]. The reproductive period for $R$. chensinensis is dependent on latitude and altitude and usually occurs from February to June following hibernation. However, one specific physiological phenomenon that occurs in $R$. chensinensis is that the oviduct abnormally expands prior to hibernation and not during the breeding period. Moreover, dessicated oviduct of the female $R$. chensinensis, Oviductus Ranae, is a valuable Chinese crude drug and is recorded in the Pharmacopoeia of the People's Republic of China (2005 edition) [36]. In the application of Oriental medicine, oviduct of Rana chensinensis is used to replenish the kidney essence, to nourish the yin and to moisten the lung [38]. The aim of present study was to investigate immunoreactivity of the $c$-kit receptor in the oviduct of $R$. chensinensis during the prehibernation period and to elucidate the relationship between the $c$-kit receptor and oviducal hypertrophy in $R$. chensinensis.

In October, 2010, ten adult female Chinese brown frogs (Rana chensinensis) were obtained during the prehibernation period from Jilin Baekdu Mountain Chinese Brown Frog Breeding Farm, Jilin Province (12540'E-12756'E, $42^{\circ} 31^{\prime} \mathrm{N}-44^{\circ} 40^{\prime} \mathrm{N}$ ), China (Fig. 1). All the animals were treated in accordance with the National Animal Welfare Legislation. All experimental procedures were carried out in accordance with the guidelines established by the Beijing Forestry University. Both the left and right oviducts were collected from the frogs. One oviduct from the left side was immediately fixed for $12 \mathrm{hr}$ in $4 \%$ paraformaldehyde (Sigma) in 0.05 M PBS, pH 7.4, for histological and immunohistochemical observations; another oviduct from the right side was immediately stored at $-80^{\circ} \mathrm{C}$ for Western blot- 


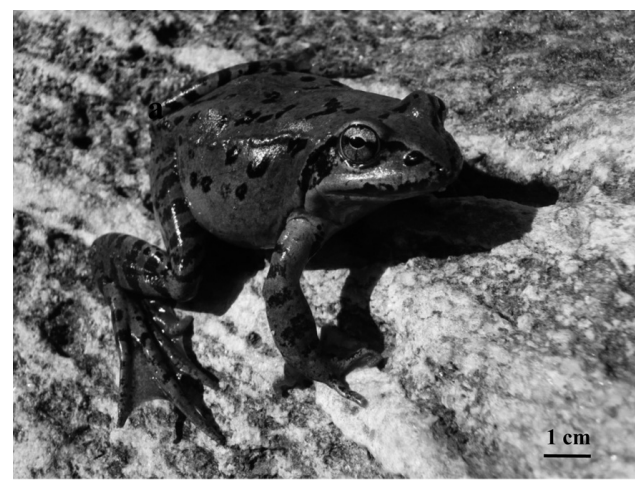

Fig. 1. A female Chinese brown frog (Rana chensinensis).

ting detection.

Oviduct samples were dehydrated in an ethanol series and embedded in paraffin wax. Serial sections $(4 \mu \mathrm{m})$ were mounted on slides coated with poly-L-lysine (Sigma). Some sections were stained with hematoxylin-eosin (HE) for observations of general histology.

Serial sections of oviducts were incubated with $10 \%$ normal goat serum to reduce background staining caused by the second antibody. The sections were then incubated with rabbit anti-rat $c$-kit receptor antiserum (1:500) (Santa Cruz Biotechnology) and rabbit anti-rat PCNA antiserum (1:500) (Santa Cruz Biotechnology) for $12 \mathrm{hr}$ at room temperature. The sections were then incubated with a second antibody, goat anti-rabbit $\operatorname{lgG}$ conjugated with biotin and peroxidase with avidin, using a rabbit ExtrAvidin staining kit (Sigma) and then visualized with $30 \mathrm{mg} \mathrm{3,3-diaminobenzidine} \mathrm{solu-}$

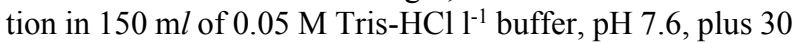
$\mu l \mathrm{H}_{2} \mathrm{O}_{2}$. The reacted sections were then counterstained with hematoxylin solution (Merck, Tokyo, Japan). Preabsorption of the antiserum was performed with an excess of antigen peptides (Sigma) for the control experiments.

The oviducts were weighed and diced into small pieces using a clean razor blade. The tissue was then homogenized in a homogenizer containing $300 \mu l$ of $10 \mathrm{mg} / \mathrm{m} l$ PMSF stock and incubated on ice for $30 \mathrm{~min}$ at $4^{\circ} \mathrm{C}$ throughout all procedures. Homogenates were centrifuged at $12,000 \times g$ for $10 \mathrm{~min}$ at $4^{\circ} \mathrm{C}$. Protein extracts $(25 \mu \mathrm{g})$ were mixed with an equal volume of $2 \times$ Laemmli sample buffer. Equal amounts of each sample were loaded and run on a $12 \%$ SDS-PAGE gel at $18 \mathrm{~V} / \mathrm{cm}$ and transferred to nitrocellulose membranes using a wet transblotting apparatus (Bio-Rad, Richmond, CA, U.S.A.). The concentration of SDS used for protein gel and protein sample buffer was $10 \%$. The membranes were blocked in 3\% BSA in TBS solution for $1 \mathrm{hr}$ at room temperature. Primary incubation of the membranes was carried out using a 1:500 dilution of both rabbit anti-rat c-kit receptor antiserum and rabbit anti-rat PCNA antiserum for $1 \mathrm{hr}$. Secondary incubation of the membrane was then carried out using a 1:1,000 dilution of goat anti-rabbit IgG tagged with horseradish peroxidase for $1 \mathrm{hr}$. Finally, the membrane was developed using $25 \mathrm{mg}$ 3,3-diaminobenzi-
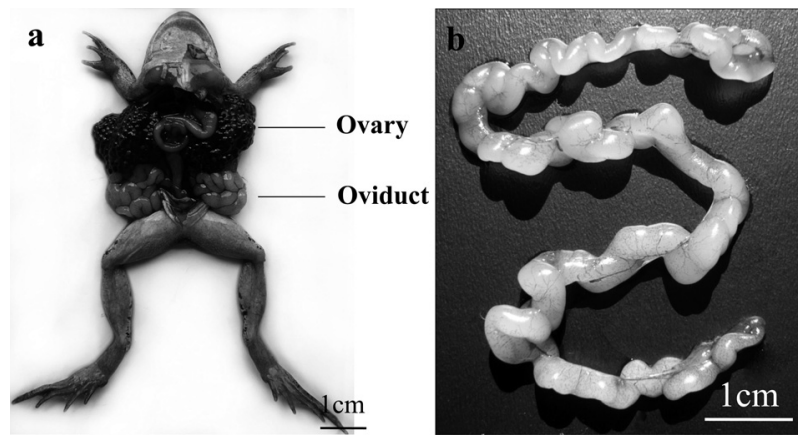

Fig. 2. Anatomic localization and morphology of an oviduct from Rana chensinensis. (a) Black ovaries in the anterior of the cavum abdominis and one pair of white oviducts in the posterior position of the cavity. (b) A dissected oviduct obtained during the prehibernation period. The scale bars represent $1 \mathrm{~cm}$.
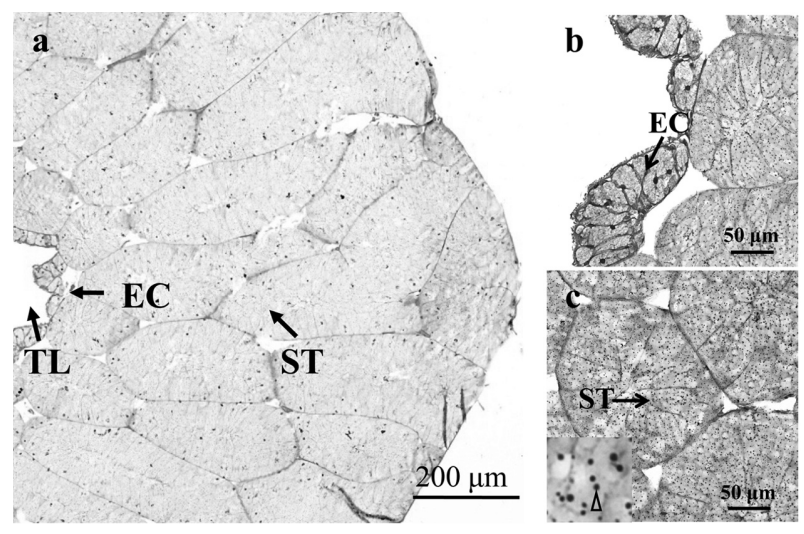

Fig. 3. Histological appearance of Rana chensinensis oviducts obtained during the prehibernation period and stained with hematoxylin-eosin (HE). During prehibernation, the tubule lumen (a), epithelial cells (b) and lobules consisting of stroma cells (c) were observed in oviduct tissues. EC: epithelial cell. ST: stroma tissue. TL: tubule lumen. The scale bars represent $200 \mu \mathrm{m}$ (a) and $50 \mu \mathrm{m}(\mathrm{b}, \mathrm{c})$.

dine solution in $25 \mathrm{~m} l$ TBS-T buffer $(0.02 \mathrm{M}$ Tris, $0.137 \mathrm{M}$ $\mathrm{NaCl}$ and $0.1 \%$ Tween-20, $\mathrm{pH} 7.6$ ) plus $3 \mu l \mathrm{H}_{2} \mathrm{O}_{2}$. Preabsorption of the antiserum was performed with an excess of antigen peptides (Sigma) for the negative control.

Anatomic and morphologic observations of oviducts of $R$. chensinensis obtained during the prehibernation period are shown in Fig. 2. Black ovaries in the anterior section of the cavum abdominis and one pair of white oviducts in the posterior section of the cavity were observed in the abdominal cavity (Fig. 2a). An enlarged view of an oviduct during the prehibernation period is shown in Fig. $2 b$.

The histological appearances of oviduct tissues from the prehibernation period in October are shown in Fig. 3. The oviduct tissues included the tubule lumen, epithelium and lobules (Fig. 3a). The lobules consisted of stroma cells (Fig. $3 \mathrm{c})$.

Immunoreactivity for the $c$-kit receptor and PCNA was observed in the oviduct tissues during the prehibernation 


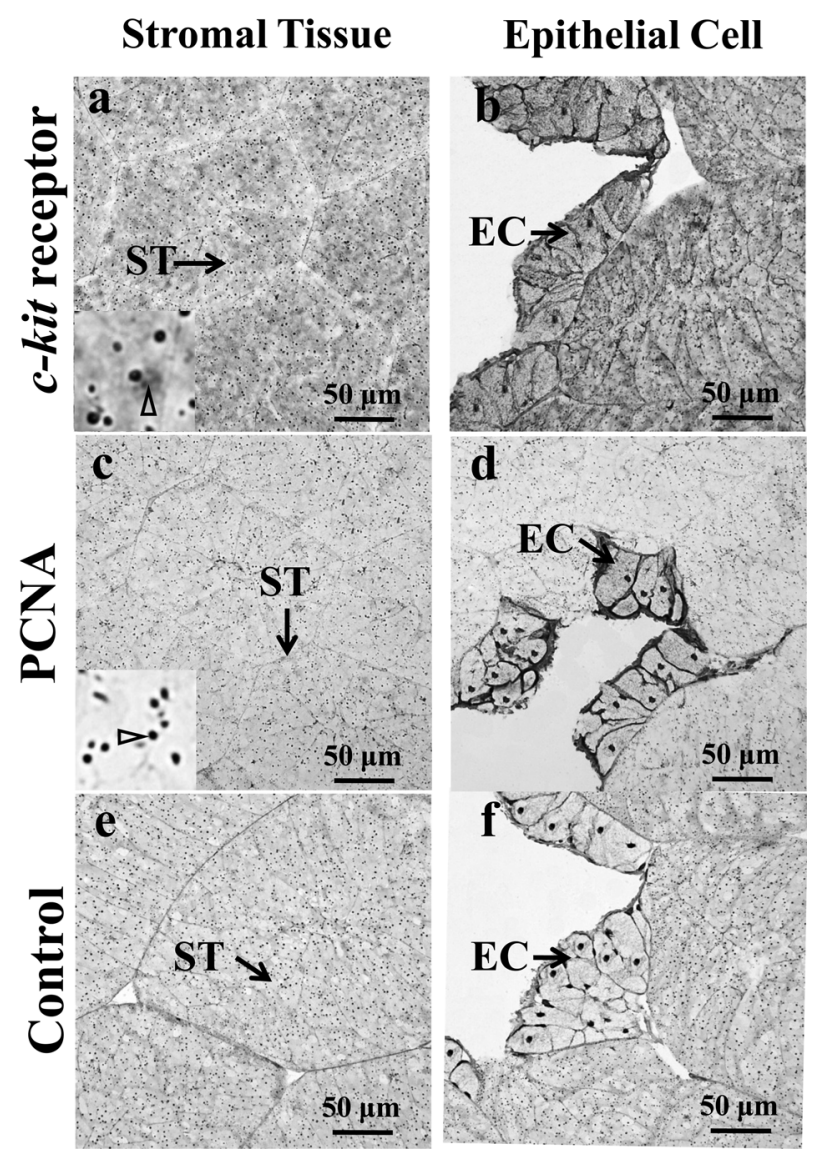

Fig. 4. Immunoreactivity of the c-kit receptor and PCNA in expanded oviduct tissues expanded of Rana chensinensis during the prehibernation period. Immunostaining for the $c$-kit receptor was observed in the cytoplasm of stroma cells (a) and epithelial cells (b) during the prehibernation period. The immunolocalization of PCNA was in the nuclei of stroma cells (c) and epithelial cells (d) during the prehibernation period. In order to clearly show the immunolocalization of $c$-kit and PCNA in the oviduct, high magnification images for $c$-kit receptor (Fig. 4, a) and PCNA (Fig. 4, c), indicated by a hollow triangle, are shown in the bottom left areas of figures. No immunostaining was detected in control sections in which the primary antibody was absorbed with an excess of antigen peptides (e, f). EC: epithelial cell. ST: stroma tissue. The scale bars represent $50 \mu \mathrm{m}$.

period (Fig. 4). The positive staining for $c$-kit receptor was also observed in the cytoplasm of stroma cells (Fig. 4a) and epithelial cells (Fig. 4b). The immunostaining of PCNA was also present in the nuclei of stroma cells (Fig. 4c) and epithelial cells (Fig. 4d). No immunoreactivity was detected in control sections in which the antiserum was preabsorbed with an excess of antigen peptides (Fig. 4e, f).

The results of Western blotting analysis for the $c$-kit receptor and PCNA in the oviduct tissues are shown in Fig. 5. Positive immunodetection of $c$-kit receptor was identified in proteins extracted from oviducts. A positive signal of PCNA was also detected in proteins extracted from ovi-

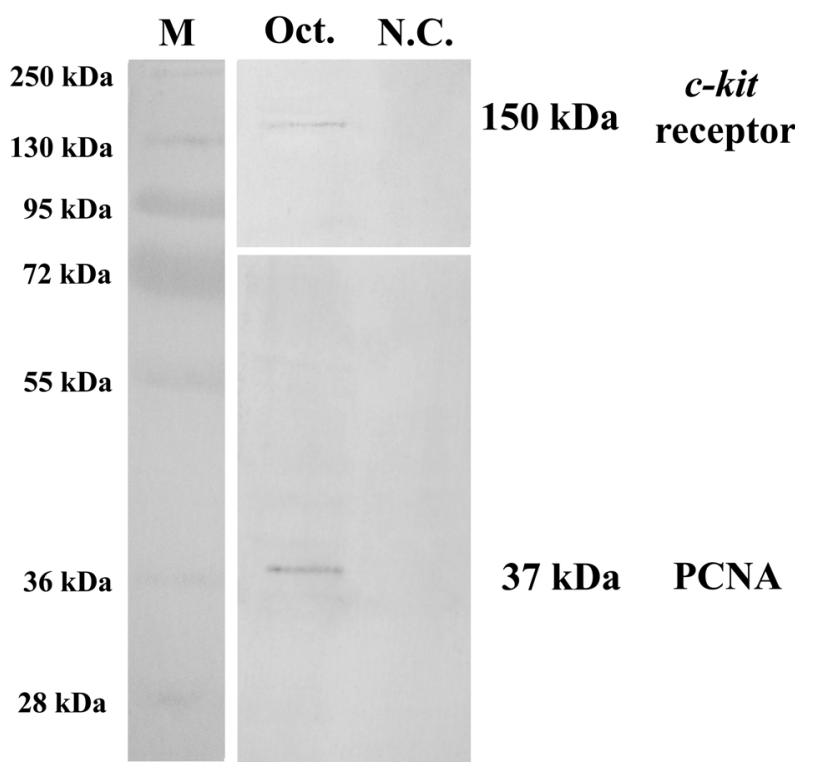

Fig. 5. Western blottings of the c-kit receptor and PCNA in the oviduct tissues of Rana chensinensis during the prehibernation period. The left side shows the $10 \%$ range prestained SDSPAGE standards (lane M). Total protein was extracted from whole oviduct tissue obtained during prehibernation. (lane Oct.). Preabsorption of the antiserum with an excess of antigen peptides was used for the negative control on the right side (lane $\mathrm{N}$. C.). The positive bands of $c$-kit receptor and PCNA were observed in the positions of approximately 150 and $37 \mathrm{kDa}$, respectively.

ducts. No immunostaining was detected for the $c$-kit receptor and PCNA when using preabsorption of the antiserum with an excess of antigen peptides (Fig. 5, lane N.C.). The $c$ kit receptor and PCNA antibodies detected proteins in oviduct tissues that migrated to a position of approximately 150 and $37 \mathrm{kDa}$.

The present results clearly demonstrated that immunoreactivity for the $c$-kit receptor was present in oviducal epithelial cells and stroma cells of $R$. chensinensis during the prehibernation period. The presence of the $c$-kit receptor protein was confirmed by Western blotting analyses carried out in the enlarged oviduct tissues. These findings suggested that the $c$-kit receptor may play a regulatory role in oviducal hypertrophy. The present results provided a basis for future detailed investigation of regulatory factors in oviducal hypertrophy.

Ovarian estrogens control development of sex accessory structures such as the hypertrophy of oviduct prior to sexual maturation and during each season prior to ovulation. The oviducts regress when estrogen synthesis declines after breeding [9]. In this study, a special physiological phenomenon, the hypertrophy of $R$. chensinensis oviducts, occurred during the prehibernation period. Histological observation indicated that epithelial cells and a large number of stromal cells were observed in oviducal tissues expanded during the prehibernation period. These findings implied that the 
hypertrophy of the oviduct was independent of ovarian steroid hormones, which could mean that locally produced intrinsic regulators might play a role in the oviducal hypertrophy of $R$. chensinensis. Cell growth and differentiation are controlled by a number of regulatory factors, including steroid hormones and peptide growth factors [30]. It is becoming increasingly evident that nuclear proto-oncogenes play a key role in coordinating steroid hormone actions in different tissues [30]. It is well documented that the $c$-kit receptor has important roles in the reproductive system because it is involved in almost all aspects of development and growth, especially cell survival, proliferation, differentiation and migration [2, 4, 11, 20, 21, 23, 25]. Evidence from humans also indicated that $c$-kit receptor was expressed in interstitial cells in the human fallopian tube [34]. The present study was the first demonstration of the expression of the $c$-kit receptor in the oviduct of vertebrates besides humans. Aberrant ligand-independent activation of the $c$-kit receptor has been implicated in the development and progression of tumors, in particular those of stroma origin $[10,17]$. Although we do not understand the importance of the $c$-kit receptor in reproduction of $R$. chensinensis, the results of this study showed that the $c$-kit receptor was present in oviduct tissues expanded during the prehibernation period. This suggested that as the intrinsic regulator, the $c$-kit receptor might play a regulatory role in oviducal hypertrophy.

The $c$-kit receptor is a higher conservative molecule, and its cDNA has been isolated in other vertebrates, such as the chicken [31], Xenopus [3, 15] and zebrafish [28]. In this study, we carried out immunohistochemistry for $c$-kit receptor protein in oviduct tissues using a rabbit polyclonal anti$c$-kit protein antibody, and the results showed that the $c$-kit receptor protein was predominantly localized in epithelial cells and stroma cells during the prehibernation period. To test our immunohistochemical results, we also performed Western blot analysis of the c-kit protein in an oviducal extract of $R$. chensinensis, and the results indicated that the polyclonal antibody recognized a single protein of about $150 \mathrm{kDa}$ in the oviduct tissue of this species. Similar evidence has also been reported in Rana esculenta; that is, the $c$-kit receptor was present in testicular tissues, and the $c$-kit antibody recognized a protein band of a similar size, approximately $150 \mathrm{kDa}$, in the germinal epithelium [29]. The most commonly used method to evaluate cellular proliferation is PCNA immunostaining. PCNA is the auxiliary subunit of DNA polymerase delta and is also involved in several additional processes in the nucleus, most notably DNA repair [24]. In the present study, to identify further oviducal epithelial cell and stroma cell proliferation and differentiation in $R$. chensinensis during the prehibernation period, oviducal tissues were also evaluated by both Western blotting and immunohistochemical detection of PCNA. The positive expression of PCNA suggested that mitotic activity of oviducal epithelial and stroma cells of $R$. chensinensis occurs during the prehibernation period. Taken together, these results indicated that the intrinsic regulators including the $c$ - kit receptor might play a regulatory role in oviducal cell proliferation and differentiation in $R$. chensinensis. Future studies will be necessary to investigate steroid hormone concentrations and differential expression of the $c$-kit receptor during the pre- and posthibernation periods.

We wish to express our gratitude to Dr. Scott Kavanaugh (Department of Integrative Physiology, University of Colorado at Boulder, CO, U.S.A.) for reading the revised manuscript and for his valuable suggestions. This study is supported by Grants-in-Aid from the Program for National Undergraduate Innovative Projects (091002217) of the Education Ministry of P. R. China, and also the Program for Changjiang Scholars and Innovative Research Team in University (IRT0607).

\section{REFERENCES}

1. Besmer, P., Murphy, J. E., George, P. C., Qiu, F. H., Bergold, P. J., Lederman, L., Snyder, H. W. Jr., Brodeur, D., Zuckerman, E. E. and Hardy, W. D. 1986. A new acute transforming feline retrovirus and relationship of its oncogene v-kit with the protein kinase gene family. Nature 320: 415-421.

2. Besmer, P., Manova, K., Duttlinger, R., Huang, E. J., Packer, A., Gyssler, C. and Bachvarova, R. F. 1993. The kit-ligand (steel factor) and its receptor c-kit/W: pleiotropic roles in gametogenesis and melanogenesis. Dev. Suppl. 125-137.

3. Baker, C. V., Sharpe, C. R., Torpey, N. P., Heasman, J. and Wylie, C. C. 1995. A Xenopus c-kit-related receptor tyrosine kinase expressed in migrating stem cells of the lateral line system. Mech. Dev. 50: 217-228.

4. Bernex, F., De Sepulveda, P., Kress, C., Elbaz, C., Delouis, C. and Panthier, J. J. 1996. Spatial and temporal patterns of c-kitexpressing cells in WlacZ/t and WlacZ/WlacZ mouse embryos. Development 122: 3023-3033.

5. Chabot, B., Stephenson, D. A., Chapman, V. M., Besmer, P. and Bernstein, A. 1988. The proto-oncogene c-kit encoding a transmembrane tyrosine kinase receptor maps to the mouse $\mathrm{W}$ locus. Nature 335: 88-89.

6. Columbo, M., Horowitz, E. M., Botana, L. M., MacGlashan, D. W. Jr., Bochner, B. S., Gillis, S., Zsebo, K. M., Galli, S. J. and Lichtenstein, L. M. 1992. The human recombinant c-kit receptor ligand, rhSCF, induces mediator release from human cutaneous mast cells and enhances IgE dependent mediator release from both skin mast cells and peripheral blood basophils. J. Immunol. 149: 599-608.

7. Dastych, J. and Metcalfe, D. D. 1994. Stem cell factor induces mast cell adhesion to fibronectin. J. Immunol. 152: 213-219.

8. Driancourt, M. A., Reynaud, K., Cortvrindt, R. and Smitz, J. 2000. Roles of KIT and KIT LIGAND in ovarian function. Rev. Reprod. 5: 143-152.

9. David, O. N. 2007. Comparative Aspects of Vertebrate Reproduction in Vertebrate Endocrinology, 1st ed., Academic Press, California.

10. Duffaud, F. and Le Cesne, A. 2009. Imatinib in the treatment of solid tumours. Target. Oncol. 4: 45-56.

11. Fleischman, R. A. 1993. From white spots to stem cells: the role of the Kit receptor in mammalian development. Trends. Genet. 9: 285-290.

12. Geissler, E. N., Ryan, M. A. and Housman, D. E. 1988. The dominant-white spotting (W) locus of the mouse encodes the ckit proto-oncogene. Cell 55: 185-192. 
13. Hutt, K. J., McLaughlin, E. A. and Holland, M. K. 2006. Kit ligand and c-Kit have diverse roles during mammalian oogenesis and folliculogenesis. Mol. Hum. Reprod. 12: 61-69.

14. Izquierdo, M. A., Van der Valk, P., Van Ark-Otte, J., Rubio, G., Germa-Lluch, J. R., Uede, R. and Scheper, R. J. 1995. Differential expression of the c-kit proto-oncogene in germ cell tumours. J. Pathol. 177: 253-258.

15. Kao, K. R. and Bernstein, A. 1995. Expression of Xkl-1, a Xenopus gene related to mammalian c-kit, in dorsal embryonic tissue. Mech. Dev. 50: 57-69.

16. Lammie, A., Drobnjak, M., Gerald, W., Saad, A., Cote, R. and Cordon-Cardo, C. 1994. Expression of c-kit and kit ligand proteins in normal human tissues. J. Histochem. Cytochem. 42: $1417-1425$.

17. Lasota, J. and Miettinen, M. 2008. Clinical significance of oncogenic KIT and PDGFRA mutations in gastrointestinal stromal tumours. Histopathology 53: 245-266.

18. Li, Y., Oral, O., Abe, K., Eto, K. and Abé, S. 2008. The roles of pericystic cells and Sertoli cells in spermatogonial proliferation stimulated by some growth factors in organ culture of newt (Cynops pyrrhogaster) testis. Gene Comp. Endocrinol. 159: 80-87.

19. Majumder, S., Brown, K., Qiu, F. H. and Besmer, P. 1988. ckit protein, a transmembrane kinase: identification in tissues and characterization. Mol. Cell. Biol. 8: 4896-4903.

20. Matsui, Y., Zsebo, K. M. and Hogan, B. L. 1990. Embryonic expression of a haematopoietic growth factor encoded by the S1 locus and the ligand for c-kit. Nature 347: 667-669.

21. Manova, K., Huang, E. J., Angeles, M., De Leon, V., Sanchez, S., Pronovost, S. M., Besmer, P. and Bachvarova, R. F. 1993. The expression pattern of the c-kit ligand in gonads of mice supports a role for the c-kit receptor in oocyte growth and in proliferation of spermatogonia. Dev. Biol. 157: 85-99.

22. Mitsunari, M., Harada, T., Tanikawa, M., Iwabe, T., Taniguchi, F. and Terakawa, N. 1999. The potential role of stem cell factor and its receptor c-kit in the mouse blastocyst implantation. Mol. Hum. Reprod. 5: 874-879.

23. Mackenzie, M. A., Jordan, S. A., Budd, P. S. and Jackson, I. J. 1997. Activation of the receptor tyrosine kinase Kit is required for the proliferation of melanoblasts in the mouse embryo. Dev. Biol. 192: 99-107.

24. Maga, G. and Hubscher, U. 2003. Proliferating cell nuclear antigen (PCNA): a dancer with many partners. J. Cell. Sci. 116: 3051-3060.

25. Molyneaux, K. and Wylie, C. 2004. Primordial germ cell migration. Int. J. Dev. Biol. 48: 537-544.

26. Nocka, K., Majumder, S., Chabot, B., Ray, P., Cervone, M., Bernstein, A. and Besmer, P. 1989. Expression of c-kit gene products in known cellular targets of $\mathrm{W}$ mutations in normal and $\mathrm{W}$ mutant mice - evidence for an impaired c-kit kinase in mutant mice. Genes Dev. 3: 816-826.

27. Nocka, K., Buck, J., Levi, E. and Besmer, P. 1990. Candidate ligand for the c-kit transmembrane kinase receptor: KL, a fibroblast derived growth factor stimulates mast cells and erythroid progenitors. EMBO J. 9: 3287-3294.

28. Parichy, D. M., Rawls, J. F., Pratt, S. J., Whitfield, T. T. and Johnson, S. L. 1999. Zebrafish sparse corresponds to an ortho- logue of c-kit and is required for the morphogenesis of a subpopulation of melanocytes, but is not essential for hematopoiesis or primordial germ cell development. Development 126: 3425-3436.

29. Raucci, F. and Di Fiore, M. M. 2007. The c-kit receptor protein in the testis of green frog Rana esculenta: seasonal changes in relationship to testosterone titres and spermatogonial proliferation. Reproduction 133: 51-60.

30. Schuchard, M., Landers, J. P., Sandhu, N. P. and Spelsberg, T. C. 1993. Steroid hormone regulation of nuclear protooncogenes. Endocr. Rev. 14: 659-669.

31. Sasaki, E., Okamura, H., Chikamune, T., Kanai, Y., Watanabe, M., Naito, M. and Sakurai, M. 1993. Cloning and expression of the chicken c-kit proto-oncogene. Gene 128: 257-261.

32. Strohmeyer, T., Reese, D., Press, M., Ackermann, R., Hartmann, M. and Slamon, D. 1995. Expression of the c-kit protooncogene and its ligand stem cell factor (SCF) in normal and malignant human testicular tissue. J. Urol. 153: 511-515.

33. Shafik, A., El-Sibai, O. and Shafik, I. 2004. Identification of ckit-positive cells in the uterus. Int. J. Gynecol. Obstet. 87: 254255.

34. Shafik, A., Shafik, A. A., El Sibai, O. and Shafik, I. A. 2005. Specialized pacemaking cells in the human Fallopian tube. Mol. Hum. Reprod. 11: 503-505.

35. Tsai, M., Takeishi, T., Thompson, H., Langley, K. E., Zsebo, K. M., Metcalfe, D. D., Geissler, E. N. and Galli, S. J. 1991. Induction of mast cell proliferation, maturation, and heparin synthesis by the rat c-kit ligand, stem cell factor. PNAS 88: 6382-6386.

36. The Pharmacopoeia Commission of PRC. 2000. Pharmacopoeia of the People's Republic of China, English Edition 3rd ed., The People's Medical Publishing House. Beijing.

37. Winter, W. E., Seidman, J. D., Krivak, T. C., Chauhan, S., Carlson, J. W., Rose, G. S. and Birrer, M. J. 2003. Clinicopathological analysis of c-kit expression in carcinosarcomas and leiomyosarcomas of the uterine corpus. Gynecol. Oncol. 91: 3-8.

38. Xuegan, Y., Yiquan, W., Kaiya, Z. and Zhongquan, L. 2002. Authentication of oviductus ranae and its original animals using molecular marker. Biol. Pharm. Bull. 25: 1035-1039.

39. Yarden, Y., Kuang, W. J., Yang-Feng, T., Coussens, L., Munemitsu, S., Dull, T. J., Chen, E., Schlessinger, J., Francke, U. and Ullrich, A. 1987. Human proto-oncogene c-kit: a new cell surface receptor tyrosine kinase for an unidentified ligand. EMBO. J. 6: 3341-3351.

40. Yee, N. S., Paek, I. and Besmer, P. 1994. Role of kit-ligand in proliferation and suppression of apoptosis in mast cells: basis for radiosensitivity of white spotting and steel mutant mice. $J$. Exp. Med. 179: 1777-1787.

41. Yao, K. and Ge, W. 2010. Kit system in the zebrafish ovary: evidence for functional divergence of two isoforms of kit (kita and kitb) and kit ligand (kitlga and kitlgb) during folliculogenesis. Biol. Reprod. 82: 1216-1226.

42. Zhang, Z., Zhang, B., Nie, X., Liu, Q., Xie, F. and Shang, D. 2009. Transcriptome analysis and identification of genes related to immune function in skin of the Chinese brown frog. Zool. Sci. 26: 80-86. 